\section{Society for Freedom in Science}

FouR years ago, a circular letter was sent to a few scientific men suggesting the formation of a new society to promote the causes of pure science and of freedom in science. A group of thirty was thus formed, which became the nucleus of the Society for Freedom in Science. The Society has recently issued. a statement of its purpose and aims, which are summed up in five propositions; put briefly, these are: (1) increase of knowledge by scientific research and its diffusion have a primary human value; (2) science can only flourish in an atmosphere of freedom; (3) scientific life should be autonomous; (4) conditions of research appointments should give workers freedom to choose their own problems; (5) scientific men in countries not under dictatorial rule should co-operate to maintain freedom of research.

The Society claims a present membership of 134, chiefly as the result of correspondence and the circulation of memoranda; but an effort is now being made to increase this number, so as to have firm backing for the Society's objects. It is feared that with the approaching period of reconstruction those who stress the applications of science to the detriment of so-called pure science and support the view that research should be centrally planned will be allowed undue influence, and the Society hopes to be in a position to insist on the claim for freedom in science. The Society is an informal body, with no rules, no regular subseription and no official president. Its affairs are conducted by a committee consisting of Dr. J. R. Baker, Prof. V. H. Blackman, Mr. R. Brown, Prof. J. A. Crowther, Prof. M. Polanyi, Dr. L. E. Sutton, Prof. A. G. Tansley and Prof. A. E. Trueman; the honorary secretary is Dr. J. R. Baker, University Museum, Oxford, from whom particulars can be obtained.

\section{Visual Education}

Mr. G. Patrick Meredith of the Education Department, University College, Exeter, took up the investigation of the use of visual media in education in 1940 , and his lectureship was converted in 1941 into a lectureship in visual education--a novel appointment. The work expanded. The accommodation and equipment provided enabled a centre to be established with a staff which now includes an assistant lecturer, Dr. Renée Marcousé. Their researches on the comparative values of different visual teaching techniques were descriked at a conference held at the centre during July 1-2. One of the most interesting features was the testimony of the teachers who took part in the research. Their enthusiasm for the new media was striking and the demand for new materials and methods was made clear. The following subjects were included in the discussions: the design of the experiment, the statistical techniques and interpretation of the results (including a new technique of analysis); classroom methods, the film and still pictures used; the children's responses; the functions of the museums, exhibitions and other resources; and lastly, the planning of edueational film production. The speakers included Mr. G. Patrick Meredith, Dr. Renée Marcousé, Mr. Bernard Gillett, Mr. Edgar Anstey, Mr. Neilson Baxter and the teachers concerned in the research. Representatives of the museums, film industry and Board of Education were present. A detailed report is to be published in the autumn.

\section{Carnegie Corporation of New York:}

Annual Report

THE annual report of the Carnegie Corporation of New York, for the year ended September 30, 1943, includes the reports of the president, Mr. W. A. Jessup, and of the secretary and of the treasurer, and gives a complete.list of grants voted during the year totalling $2,562,900$ dollars. Income for the year was 4,114,952 dollars in the Main Endowment Fund applicable to the United States, and 355,288 dollars in the fund applicable to the British. Dominions and Colonies, the interest on the funds being equivalent to $2 \cdot 7$ per cent on investment securities, as compared with a yield of $4 \cdot 5$ per cent in the period 1932-33. The president points out that by means of reserves for various purposes the Corporation has spread allocations for the payment of appropriation for certain long-time interests over a period of years and has built up a depreciation reserve as partial protection of the endowment and legacy. The fact that the income to-day is only three fifths of the income ten years ago has, however, modified the grant-making policy of the Corporation. The Trustees are faced with the necessity of reducing either the number of grants made or the amounts involved, and possibly both.

The president also refers to the growing practice among donors of naming the specific purposes for which money is to be used. A recent inquiry among some twenty institutions showed that less than 10 per cent of the current gifts were free to be administered or allocated by the board of trustees and executive officers of the institutions. The president points out that in many instances a better method would be for the giver to expect the recipient institution to be capable and informed enough, and ready to accept, a larger share of responsibility for determining the allocation of gifts to research, to improvement in teaching, for equipment and for other important purposes within its own organization. Foundations such as the Carnegie Corporation have an obligation to continue to use their freedom from local and regional prejudices and from the pressures to which even privately endowed educational institutions are suffering, to foster new ideas and to nurture the pioneer spirit in education. Speaking of experimental projects, he said that those responsible should not expect support to be continued long after the undertaking has passed the experimental stage. These views are based on a review of the record of academic and foundation experience in administering grants during the past thirty years. During the year 1942-43, 12,000 dollars were voted to the Institute of International Education for continued support of the American University Union in London ; grants totalling 225,300 dollars were made to agencies and organizations concerned with inter. national understanding including the Carnegie Endowment for International Peace, the Instjtute of Pacific Relations and the Ethnogeographic Board under the National Research Council.

\section{Gas Research Board: Annual Report}

The forrth annual report of the Council of the Gas Research Board has a special importance, covering as it does a period when the Board became associated with the Department of Scientific and Industrial Research. This, however, is only another step in a long course of development extending over nearly half a century, during which the gas industry 